KENOSIS : JURNAL KAJIAN TEOLOGI

ISSN 2460-6901(Print), 2656-4483 (Online)

https://e-journal.iaknambon.ac.id/index.php/KNS

DOI: 10.37196/kenosis.v1i1.286

\title{
KESELAMATAN BAGI TUNAS LIAR?: \\ Tafsiran terhadap alegori keselamatan dalam Roma 11:17-24
}

\section{Vincent Kalvin Wenno dan Aleta Apriliana Ruimassa}

\author{
Institut Agama Kristen Negeri Ambon \\ Jalan Dulog, Halong Atas, Desa Halong, \\ Kec. Baguala, Kota Ambon, Provinsi Maluku \\ vincent.wenno@iaknambon.ac.id \\ Universitas Kristen Indonesia Maluku \\ Jalan Ot Pattimaipauw RT.003/RW.003 Talake \\ , Kel Wainitu, Kec. Nusaniwe, Kota Ambon, Provinsi Maluku \\ aruimassa@gmail.com
}

\begin{abstract}
The concept of salvation in the New Testament is an interesting one to analyze. Christians often use the concept to see the world as different from their own identity. One of these is Romans 11: 17-24, which talked about salvation for Gentiles and Jews. In this article, the text is analyzed using critical historical interpretation to trace the historicity and meaning of the text based on the consideration of various aspects in the method of critical historical interpretation. After being analyzed, several things were found. First, Israel's rejection resulted in opening up salvation for people outside Israel Second, the person who has been chosen to be saved must take responsibility for the choice because the choice is based on compassion and grace. Third, in salvation, everyone is treated the same and will suffer the same consequences.
\end{abstract}

Keywords: Salvation, Inclusion, Historical Criticism, Paul

\begin{abstract}
Abstrak
Pokok-pokok keselamatan yang terurai dalam Perjanjian Baru merupakan hal yang menarik untuk dianalisis. Kekristenan sering menggunakan konsep keselamatan untuk melihat dunia yang berbeda dengan identitas mereka sendiri. Salah satunya adalah teks Roma 11:17-24 yang berbicara tentang keselamatan bagi orang bukan Yahudi dan orang Yahudi. Dalam artikel ini,
\end{abstract}


teks tersebut dianalisis secara deskriptif kualitatif dengan mempertimbangkan interpretasi gambaran visual dalam teks. Setelah dianalisis, maka ada beberapa hal yang ditemukan; Pertama, penolakan Israel mengakibatkan terbukanya keselamatan bagi orang di luar Israel. Kedua, orang yang telah dipilih untuk menjadi selamat harus bertanggung jawab atas pilihan, yang didasarkan pada belas kasih dan anugerah semata. Ketiga, bentuk respons keselamatan adalah sikap percaya dan taat.

Kata Kunci: Keselamatan, Inklusif, Kritik Historis, Paulus

\section{PENDAHULUAN}

Keselamatan menurut tulisan-tulisan Paulus merupakan salah satu pokok kajian yang masih relevan untuk dibahas. Pokok-pokok itu di kemudian hari menjadi landasan pemikiran orang beriman untuk merumuskan pemahamannya tentang keselamatan. Tetapi pemahaman tentang keselamatan harus dipahami dalam kerangka pemahaman Paulus yang berelasi dengan Israel dan bangsa-bangsa di luar Israel. Pokok tentang keselamatan itu bisa ditemukan dalam berbagai tulisan Paulus dalam Perjanjian Baru. Tetapi artikel ini akan berfokus pada rangkaian panjang alegori dan pernyataan retorisnya dalam Roma 9-11, dengan fokus utama pada alegori dalam 11:17-24.

Pembahasan tentang keselamatan dalam studi tentang Paulus dan suratsuratnya mulai mengalami pergeseran. Di masa lalu, interpretasi tradisional yang sering diulang melihat Paulus bertentangan dengan Yudaisme. Pandangan ini menganggap Paulus menanggapi pandangan Yahudinya. Ia melakukan kritik dan bereaksi terhadap masa lalu Yahudinya sendiri. Kemungkinan konsekuensi dari posisi ini adalah, Paulus mendistorsi Yudaisme. Teologi Kristennya yang berkembang pada dasarnya dipandang sebagai polemik melawan Yudaisme. Bias ini dikatakan memberikan dasar kanonik untuk anti-Yudaisme Kristen, sebuah tuduhan yang tampaknya sangat menantang sehubungan dengan kristologi Paulus (misalnya, dugaan hubungan eksklusif antara Kristus dan hukum) dan kemungkinan masa depan bagi Israel. $^{1}$

Tetapi penekanan ini mulai berubah. Paulus mengidentifikasi dirinya sebagai Rasul bagi bangsa-bangsa lain dan terutama misi non-Yahudi yang membentuk pesan 
Paulus. Gagasan Paulus tentang Israel, sebagaimana dikembangkan secara eksplisit dalam Roma 9-11, dipengaruhi paling signifikan oleh misinya kepada bangsa-bangsa lain. Implikasi dari pernyataan ini adalah bahwa Paulus memperluas pemahamannya tentang Israel dengan memasukkan orang-orang bukan Yahudi, bukan menyerang dasar-dasar teologi Israel. Penting untuk ditekankan bahwa meskipun Roma 9-11 memiliki ciri-ciri yang unik, argumentasi dan fokusnya khas Paulus dan kontribusinya pada pemikiran Kristen sebagai hasil dari orang-orang bukan Yahudi.

Gambaran tentang Keselamatan menurut Paulus itu ditemukan dalam Roma 11:11-24. Sebuah risalah retoris yang panjang dan kadang membingungkan dalam kaidah retoris dilakukan Paulus pada suratnya itu. Pada ayat 17-24 Paulus menggunakan alegori pohon zaitun untuk mengartikulasikan visi pengikut Yesus nonYahudi dan Yahudi yang bergabung bersama dalam sebuah rumah Israel. Untuk memperjelasnya, ia menggambarkan teknik pertanian kuno yang biasanya digunakan untuk merangsang produksi buah pohon zaitun. Gambaran ini merujuk pada kebiasaan khusus Yudea kuno yang melibatkan Tuhan atas real estate pertanian dan produk pertanian. $^{2}$

Secara umum disepakati bahwa keselamatan diberikan bagi tunas liar yang dicangkokkan. Jadi, alegori Paulus dianggap sebagai suatu konsep keselamatan yang terbuka bagi orang di luar Israel. Paulus dianggap menggugah Israel dengan mencangkokkan tunas liar itu. Artikel ini bertujuan untuk membaca keselamatan dalam alegori ayat 17-24 dalam kesadaran akan keselamatan yang inklusif. Keselamatan bagi tunas liar akan diskusikan dengan keselamatan yang sudah diperoleh Israel.

\section{METODE PENELITIAN}

Penelitian secara kualitatif deskriptif, menganalisis teks dan berbagai sumber pustaka untuk melakukan survei dan kajian dari berbagai ahli dalam proses penafsiran. Untuk mendukung proses penafsiran dan analisis, maka peneliti menggunakan sejumlah sumber pustaka dari buku, jurnal dan berbagai tulisan ilmiah. Teks utama yang dikaji adalah alegori Pohon Zaitun dalam Roma 11:17-24. Alegori tersebut merupakan gambaran visual yang akan diinterpretasikan seperti semua pengalaman 
indrawi, interpretasi gambaran visual dalam alegori itu tetap memperhatikan situasi kultural dan sosio-historis. ${ }^{3}$

\section{HASIL DAN PEMBAHASAN}

\section{Struktur dan Bentuk Roma 11:17-24}

Analisis yang dilakukan oleh Robert Jewett terhadap struktur teks ini menemukan berbagai pendapat para ahli Perjanjian Baru dalam pemetaan bagian struktur dan keluasan teks pada Roma $11 .{ }^{4}$ Pertama, ada beberapa yang melihat Roma 1-36 sebagai suatu kesatuan, atau bagian ayat Roma 11:11-24 merupakan cerita panjang dari 10:16-11:36. Kedua, 11:11-24 sebagai kesatuan yang terbagi-bagi, atau sebagai satu rangkaian cerita yang dibagi ke dalam sub cerita. Contohnya, C. K. Barrett membagi struktur teks 11:11-24 ke dalam 3 bagian, yaitu 11:11-12, 13-16, dan $17-24 .^{5}$ Sub cerita itu lebih dikenal sebagai paragraf-paragraf, yang terdiri dari beberapa ayat. Sedangkan Jewett membagi teks ini berdasarkan analogi retoris ke dalam empat bagian: Tesis pada 11:11, entimem/silogisme retorik logis dalam 12-15, entimem alegoris pada analogi Paulus tentang pohon zaitun dalam 16-21, dan bagian kesimpulan pada 22-24 ${ }^{6}$. Pembagian tersebut lebih mudah dipahami karena pada bagian ayat 15-16 dan 21-22, Paulus melakukan peralihan retorisnya untuk masuk ke penjelasan (ayat) berikutnya.

Dari berbagai pernyataan di atas, tampaknya dengan mudah menggolongkan ayat 17-24. Penggolongan itu didasarkan pada kesamaan muatan retoris, yang dibingkai dalam penjelasan alegoris. Untuk itu, studi ini akan berfokus pada bagian tersebut. Namun, dalam kerangka yang lebih luas, ayat 17-24 tidak bisa terlepas dari ayat sebelum dan sesudahnya. Terutama pada bagian ayat 16 , yang merupakan suatu peralihan. Lebih tepatnya, peralihan dari pernyataan retoris kepada pernyataan alegoris tentang keselamatan. Pernyataan itu dimulai dari ayat 16 tetapi terbagi atas dua bagian. Bagian pertama: tentang roti sulung (16a), dan bagian kedua tentang akar dan cabang yang kudus (16b). Paulus tidak menguraikan lebih lanjut tentang roti sulung itu, ia malah menggunakan alegori yang dikembangkan dari ayat 16b. Jadi, dalam hal ini posisi $16 \mathrm{~b}$ bisa menjadi bagian dalam 17-24, tetapi sebagai pengantar untuk masuk ke dalam ayat 17-24. 
Bentuk teks ini masih diperdebatkan. Banyak para ahli yang dikutip dalam Jewett mengidentifikasi teks ini sebagai alegori, meskipun secara detail masih dipertanyakan bentuk alegori tersebut, karena ketidakjelasan perbandingannya. Anderson dan Hans-Josef Klauck, sebagaimana yang dikutip oleh Jewett menjelaskan dua hal yang berbeda. Bagi Anderson, bentuk dari Roma 11 lebih dekat ke fable daripada alegori, Paulus tidak lebih kurang dari orang yang tidak tahu apa-apa tentang alegori/dengan sengaja tidak menggunakan teknik retorik dari abad pertama. ${ }^{7}$ Baginya teks ini adalah extended metaphore dibandingkan dengan alegori. Sedangkan bagi Klauck, teks ini merupakan alegori. Sayangnya Paulus bukanlah orang yang paham betul tentang teknik itu. Atau Paulus secara sederhana (datar) menjelaskan perbandingan figur Pohon Zaitun tersebut. ${ }^{8}$ Jika dilihat dalam teks tersebut, maka Pohon Zaitun lebih ditonjolkan sebagai metafora, atau metafora yang diperluas, yang memiliki arti yang sama dengan alegori.

Tujuan alegori yang dikutip Paulus, yaitu mengilustrasikan dan menyampaikan maksudnya dengan menghantar pembaca masuk dalam imajinasi visual, yang didasarkan pada fenomena pengalaman sehari-hari. Paulus mengharapkan suatu pembacaan yang imajinatif, tidak hanya kognitif mereka saja. Alegori mendukung dan menerangi argumen, sementara argumen menyediakan kerangka kerja untuk mengontekstualisasikan dan menyesuaikan makna alegori. Citra yang disampaikan secara alegoris atau metaforis umumnya merupakan sarana yang berguna untuk menilai interpretasi argumen yang ingin disampaikan. ${ }^{9}$

\section{Penggunaan Alegori Pohon Zaitun dalam ayat 16b-24}

Pohon zaitun termasuk dalam spesies Olea Europaea L. dan biasanya dibagi menjadi dua sub-spesies: Olea Europaea Sativa (termasuk zaitun yang dibudidayakan) dan Olea Europaea Oleaster (zaitun liar), kedua sub spesies ini berbeda antara satu dengan lainnya. Setelah penanaman, zaitun muda membutuhkan waktu yang cukup lama untuk mulai berbuah, berkisar antara enam tahun dalam kondisi yang sangat baik hingga 15 hingga 20 tahun di daerah kering. Dalam 17-24, Pohon zaitun dari kedua jenis itu digunakan Paulus untuk membandingkan tiga hal: akar, cabang dan tunas liar. Ketiganya merujuk pada budidaya pohon zaitun dalam 
dunia Yunani-Romawi. Budidaya itu lebih dikenal dengan oleikultur kuno atau segala upaya untuk produksi, pengolahan, dan pemasaran buah zaitun. ${ }^{10}$

Selain budidaya pohon zaitun, alegori Paulus menyangkut dengan teknik pencangkokan pada masa itu. Di daerah Yunani, mencangkok kultivar yang dibudidayakan ke stok/batang liar adalah metode perbanyakan yang normal untuk zaitun. Pohon zaitun muda liar digali di pegunungan dan dipindahkan ke tempat pembudidayaan dan kemudian disiram selama dua musim panas, kemudian dicangkokkan. Metode ini masih dipraktikkan di Israel, di mana pohon zaitun liar yang diambil dari hutan sebagai batang bawah dicangkokkan dengan batang atas dari pohon budidaya tertentu di kebun zaitun di sebuah desa yang dikenal berbuah. Pohon zaitun cenderung memiliki sistem akar yang lebih luas dan lebih tahan penyakit daripada varietas yang dibudidayakan.

Praktik pencangkokan di atas berbeda dengan apa yang dijelaskan oleh Paulus. Berdasarkan ayat 17-24, bagi Paulus tunas liar dicangkokkan ke pohon peliharaan/budidaya. Sedangkan dari beberapa bukti dan pada penjelasan sebelumnya, pencangkokan biasanya dari cabang yang dibudidaya ke pohon-pohon liar. ${ }^{11}$ Sejauh ini pandangan yang paling masuk akal adalah bahwa Paulus dan pendengarnya yang berbahasa Yunani sangat menyadari baik praktik yang tersebar luas di Mediterania Timur dalam mencangkok cabang zaitun yang dibudidayakan ke pohon zaitun liar dan alasan praktek itu — untuk menghasilkan lebih banyak buah. Akan tetapi, nyata bahwa apa yang digambarkan Paulus tidak sesuai dengan praktek semacam pencangkokan. Dihadapkan dengan alegori tentang batang zaitun liar yang dicangkokkan ke tanaman yang dibudidayakan, beberapa komentator berasumsi bahwa Paulus salah, karena ketidaktahuannya tentang penanaman zaitun.

Beberapa pandangan yang dirangkum Douglas Moo, ${ }^{12}$ coba untuk menjelaskan penggunaan cara pencangkokan yang keliru itu. Pertama, ada bukti dalam sumbersumber kuno yang menunjukkan bahwa petani kadang-kadang mencangkokkan tunas zaitun liar ke dalam pohon budidaya. ${ }^{13}$ Kedua, Paulus dengan sengaja mengutip sebuah praktik yang "bertentangan dengan alam" sebagai cara untuk menggambarkan kasih karunia Allah yang bekerja dalam penggabungan orang-orang bukan Yahudi dengan umat Allah (ay 24 ). ${ }^{14}$ Usaha-usaha untuk menjawab kesalahan penggunaan 
alegori tersebut tidak mampu menjelaskan apapun tentang pemikiran Paulus. Hanya saja, Paulus telah membiarkan proses teologis yang dia gambarkan mempengaruhi istilah gambarannyanya. Jadi, tidak ada kesimpulan apapun tentang ketepatan alegori itu dengan praktik pencangkokan yang sebenarnya.

Alegori dalam ayat 17-24 itu dimulai dari ayat 16b. Paulus menjelaskan tentang cabang dan akar yang saling berhubungan. Kedua hal tersebut merupakan bagian dari akar dan cabang pada penjelasan selanjutnya (17-24). Dalam penjelasan pada ayat 16b, ada gema dari Ayub 18:16; Yer. 17:8; Yeh. 31:8; Hos. 9:16 tentang ketergantungan cabang pada akarnya. Selain itu, terdapat gema tentang Tuhan Alam Semesta yang "menanam" dan menumbuhkan Israel dalam Mzm. 92:13; Yer 11:17, dan ayat-ayat itu merujuk kepada Israel sebagai tanaman atau tunas yang benar. ${ }^{15}$

Meski terdapat gema di mana-mana tentang cabang dan akar, namun agak sulit untuk mengidentifikasi kata "akar". Hal tersebut membuka ruang bagi banyak penafsir untuk menentukan kata akar sebagai personifikasi dari Kristus, ${ }^{16}$ sisa Israel yang telah menjadi Kristen, ${ }^{17}$ dan para bapa leluhur, maupun para nabi. ${ }^{18}$ Namun, ada berbagai dukungan dari penafsir untuk mengidentifikasi akar sebagai Israel yang berasal dari Abraham, ${ }^{19}$ karena ada paralel yang semakin mudah dimengerti dalam ayat 17-18 dan hubungan antara Israel dan nenek moyangnya dalam ayat $28 .{ }^{20} \mathrm{Hal}$ ini kembali menegaskan ayat dalam Yeremia 11:16 dan Hos 14:6 yang menyebut Israel sebagai pohon zaitun. ${ }^{21}$ Sedangkan cabang adalah orang percaya tapi bukan Yahudi. ${ }^{22}$

\section{Penafsiran dan Makna Alegoris Pohon Zaitun}

Paulus pada ayat 17-22 mulai memanfaatkan gambaran akar dan cabang untuk memperingatkan orang Kristen non-Yahudi. Ia memulai ayat 17 dengan menggunakan klausa bersyarat ( $e i$ de) yang diterjemahkan menjadi "jika",23 untuk klausa selanjutnya pada ayat 18 tentang "janganlah bermegah". Kedua ayat ini menjelaskan dua kondisi: Pertama, beberapa cabang telah dipatahkan (ayat 17). Ini merupakan penjelasan dalam bentuk baru terhadap kondisi Israel yang dijelaskan dalam Roma 9-11. Mereka adalah penerima berkat dari Allah melalui para leluhur, namun dipisahkan karena perbuatan dan ketidakmampuan mereka untuk percaya (ayat 7-10 \& 20). Kedua, tentang tunas liar yang “dicangkokkan”. Gambaran ini merujuk ke sapaan Paulus bagi orang Kristen bukan Yahudi pada ayat 13. Sebagai non-Yahudi, mereka tidak 
memiliki hubungan alami dengan para bapa leluhur dan janji-janji yang diberikan kepada mereka. Hanya dengan kasih karunia Allah (ayat 22) dan iman mereka (ayat 20) mereka dapat menjadi satu bagian dengan Israel. ${ }^{24}$

Pencangkokan tunas liar merupakan bentuk ketergantungan tunas liar yang susah berbuah kepada kasih karunia Allah. Orang non-Yahudi dari kelompok etnis yang berbeda telah bergabung dalam garis keselamatan yang sama dengan sisa Israel yang percaya. Mereka terlibat dalam keselamatan, tetapi bukan sebagai orang yang tidak berguna, melainkan sebagai mitra/partner bersama menuju cabang dan akar. Kata mitra tersebut berasal dari kata sugkoinwnov (sugkoinonos) yang sering digunakan untuk merujuk pada istilah koinonia dalam kaitannya dengan keanggotaan dalam komunitas kudus. ${ }^{25}$ Bentuk mitra tersebut merupakan ciri khas Paulus untuk menjelaskan koinonia ataupun persekutuan, di mana terdapat partisipasi dan keterlibatan aktif terhadap suatu hal. ${ }^{26}$

Larangan Paulus dalam ayat 18 masih menyangkut kemitraan itu. Ia memperingatkan supaya jangan bermegah terhadap cabang-cabang. Ia tidak menjelaskan kepada siapa kata itu dituju, baik kepada cabang liar atau yang masih tersisa. Usulan $\mathrm{Moo}^{27}$ adalah memahami larangan Paulus bagi kedua pihak. Ia merujuk pada Roma 14:1-15:13, di mana Paulus memiliki kepedulian untuk mendamaikan orang Yahudi dan bukan Yahudi di dalam gereja. Meski demikian Paulus tetap mengingatkan (pada ayat 18b) jika nanti orang Kristen non Yahudi tetap bermegah. Akar lah yang menopang cabang. Jadi dengan masuknya orang Kristen non Yahudi yang sangat banyak dibandingkan dengan orang Israel yang menjadi Kristen, tidak berarti Israel dibiarkan menjadi liar. Semua masih kembali ke janji Tuhan kepada para lelulur. ${ }^{28}$ Tetapi keselamatan telah membuat semua menjadi satu dan kini memiliki akar yang sama.

Ayat 19-20 mengulang (dalam bentuk berbeda) isi ayat 17. Pada bagian ini, Paulus secara spesifik merujuk pada orang non-Yahudi. ${ }^{29}$ Ia kembali menggugah rasa superioritas orang Kristen non Yahudi. Baginya, tujuan orang non-Yahudi diselamatkan untuk membuat orang Yahudi cemburu (11:11) dan kembali kepada kebenaran. Paulus menekankan bahwa sifat kemurahan dari hubungan Allah dengan manusia mengesampingkan semua kesombongan. Iman dibangun dalam relasi dengan 
Tuhan yang penuh rasa hormat dan kerendahan hati (3:27-4:5). Untuk itu orang Kristen non Yahudi sebaiknya mengambil sikap hormat.

Ayat 21 dan 21 menggambarkan perbandingan Paulus terhadap orang non Yahudi dan Yahudi, yang di dalamnya juga berisikan teguran keras. Baginya, jika Tuhan tidak menyayangkan orang Yahudi, maka hal yang sama akan berlaku bagi orang yang bukan Yahudi. Untuk itu, pada ayat setelahnya, Paulus menegaskan kembali konsep Allah yang penuh belas kasih, dan Allah yang penuh keadilan. Allah yang murka atas orang yang tidak percaya kepada-Nya, tetapi berbelas kasih bagi mereka hidup di dalam-Nya.

Keadilan Allah itu, menjadi dasar dari orang yang menerima-Nya untuk memahami pemilihan keselamatan yang didasarkan atas anugerah. Orang yang dipilih harus bertanggungjawab atas anugerah tersebut, dan sadar bahwa pemilihan tersebut atas dasar kebaikan Tuhan. Pada tingkat ini, Paulus menganggap orang non-Yahudi pun akan diperlakukan sama seperti orang Yahudi dalam pemilihan mereka. Jika mereka tidak mawas diri terhadap perintah Tuhan, maka hal yang sama akan mereka temui.

Pada bagian terakhir (ay 24), Paulus sekali lagi menegaskan bahwa Tuhan bisa saja mencangkokkan mereka (Orang Israel) meskipun dalam ketidakpercayaan. Hal ini disebabkan orang Israel belum secara definitif ditolak oleh Allah (11:1). Mereka lebih mudah kembali ke pohon sejati dibandingkan dengan cabang liar yang dicangkok. Pencangkokan orang bukan Yahudi, sebaliknya, tidak wajar dan agak berbahaya. Karena bertentangan dengan keadaan sebenarnya. ${ }^{30}$ Jadi, Pemulihan orang Yahudi, bagaimanapun, akan lebih mudah daripada panggilan orang bukan Yahudi. Jadi penolakan Israel tidak pasti, tapi sementara.

\section{Makna Keselamatan Inklusif dalam Roma 11:17-24}

Sejak awal, keterpilihan Bangsa Israel sebagai bangsa pilihan Allah tidak ada hubungannya dengan apa yang dimiliki oleh bangsa tersebut. Karman menyebutkan bahwa keterpilihan bangsa ini hanyalah oleh anugerah. Sejak keterpilihan itu juga, Allah senantiasa menunjukkan keberpihakan-Nya kepada bangsa yang sering kali juga berpaling dan tidak setia kepada-Nya. ${ }^{31}$ Alkitab mencatat bagaimana bangsa yang terpilih ini berkali-kali melakukan dosa pemberontakan kepada Allah yang tetap 
berpegang pada janji-Nya kepada para leluhur Israel. Bahkan, Paulus menyebutkan bahwa ketersandungan orang Israel yang erat kaitannya dengan penolakan mereka untuk percaya kepada Yesus, ternyata tidak mengubah kenyataan bahwa Allah tetap menjaga kesetiaan-Nya kepada bangsa ini. Oleh karena itu, tidaklah mengherankan jika keterpilihan bangsa Israel dan bagaimana Allah menunjukkan kesetiaan-Nya kepada bangsa ini tentu dapat dilihat sebagai sebuah eksklusivitas oleh bangsa-bangsa lain.

Meski keterpilihan bangsa Israel dapat dilihat sebagai sebuah eksklusivisme, tetapi sesungguhnya keselamatan yang dirancangkan oleh Allah tidak hanya untuk orang Israel. Dalam teks-teks PL, banyak kisah yang membuka paradigma keselamatan yang juga ditujukan bagi bangsa-bangsa lain oleh kehadiran bangsa Israel. Bangsa Israel dipakai oleh Allah untuk menunjukkan bahwa keterpilihan mereka hanya oleh karena anugerahNya dan respon balik dari umat yang terpilih adalah bagaimana mereka tunduk pada kedaulatan Allah dan bagaimana kehadiran mereka dapat menjadi terang bagi bangsa lain (Yes. 42:6). Oleh karena itu, ketika bangsa ini ada yang gagal untuk memenuhi keterpanggilan hidupnya sebagai umat pilihan, maka keselamatan juga dibuka bagi bangsa-bangsa lain yang mau untuk percaya. Sekali lagi, itu bukan karena bangsa-bangsa lain lebih pantas tetapi karena anugerah Allah.

Menurut Schreiner, umat Allah dipilih karena anugerah Allah. Mereka tidak dipilih karena perbedaan etnis atau moral mereka. ${ }^{32}$ Menjadi bagian dari keselamatan yang Allah rancangkan berarti membutuhkan sebuah sikap tunduk dan taat kepadaNya. Keselamatan yang Allah anugerahkan baik kepada bangsa Israel maupun kepada orang-orang Kristen mengundang mereka untuk hidup dalam sikap percaya kepada Allah. Karman menegaskan bahwa jati diri sebagai umat Allah, baik Israel maupun bukan, sama yakni bersandar penuh kepada Allah. Diangkat menjadi umat Allah bukanlah soal prestise sehingga manusia dapat menjadi sombong dan lupa bahwa itu adalah anugerah. ${ }^{33}$ Allah-lah yang mengawali akan rancangan keselamatan itu, dan Allah juga yang akan menjamin bahwa rancangan itu tetap berjalan sesuai kehendakNya. Peran serta umat Allah dalam rangka menggenapi rencana keselamatan Allah bagi dunia adalah dengan menjadi terang dan menjadi saksi-saksinya yang hidup. 


\section{KESIMPULAN}

Alegori yang terdapat di dalam teks Roma 11: 17-24 merupakan sebuah upaya yang dilakukan oleh Paulus untuk menempatkan posisi dari Bangsa Israel dalam rencana keselamatan Allah setelah mereka jatuh pada penolakan Yesus. Upaya ini tentu dapat dilihat sebagai upaya membela bangsanya sendiri karena Paulus terlihat dengan sangat jelas masih menaruh pengharapan pada keselamatan dari orang-orang Yahudi seluruhnya. Akan tetapi, teks ini juga menunjukkan sikap dari seorang Paulus yang menegaskan inklusivitas keselamatan Allah kepada bangsa-bangsa bukan Yahudi yang sudah menjadi Kristen.

Tunas liar yang kemudian dicangkokkan ke pohon zaitun merupakan suatu metode pertanian yang bertujuan untuk meremajakan pohon zaitun tersebut. Melalui gambaran tersebut, Paulus menggambarkan masuknya bangsa-bangsa bukan Yahudi yang sudah menjadi Kristen pada rancangan keselamatan yang Allah mulai dari sejak adanya leluhur Israel. Meski demikian, sama sekali tidak meniadakan Israel atau menggantikan posisi Israel sebagai umat Allah. Keterpilihan Bangsa Israel sejak semula ada dalam kedaulatan Allah, dan keterpilihan itu tetap ditegaskan melalui kesetiaan Allah bagi bangsa itu meski Israel menjadi bangsa yang tegar tengkuk.

Baik bangsa Israel maupun bangsa-bangsa bukan Yahudi yang sudah percaya kepada Kristus pada akhirnya dibawa masuk dalam rancangan keselamatan Allah bagi dunia ini. Sama seperti Bangsa Israel yang terpilih menjadi umat pilihan Allah oleh karena anugerah Allah, demikian juga dengan mereka di luar dari bangsa Israel. Menjadi umat Allah adalah sebuah anugerah yang Allah berikan, dan merespons akan pemberian tersebut maka umat Allah diminta untuk menunjukkan sikap percaya dan tunduk atas kehendak Allah. Hal itu juga berarti umat Allah dipanggil dan diutus untuk menjadi terang dan saksiNya untuk melanjutkan penggenapan karya keselamatan Allah di tengah-tengah dunia ini. 


\section{Endnotes:}

${ }^{1}$ Mary Ann Getty, "Paul and the Salvation of Israel: A Perspective on Romans 9-11," The Catholic Biblical Quarterly 50, no. 3 (1988): 456-57.

${ }^{2}$ Benjamin D. Gordon, "On the Sanctity of Mixtures and Branches: Two Halakic Sayings in Romans 11:16-24," Journal of Biblical Literature (Society of Biblical Literature, 2016), 355-56, https://doi.org/10.15699/jbl.1352.2016.2783.

${ }^{3}$ Marcus Banks and David Zeitlyn, Visual Methods in Social Research (Sage, 2015), 3.

4 Robert Jewett, Eldon Jay Epp, and Roy David Kotansky, Romans: A Commentary, Hermeneia (Minneapolis, MN: Fortress Press, 2006), 668.

5 Charles K. Barrett, The Epistle to the Romans, Revised, Black's New Testament Commentary (Peabody, Mass: Hendrickson Publishers, 1991), 211-12.

${ }^{6}$ Jewett, Epp, and Kotansky, Romans: A Commentary, 668.

${ }^{7}$ R Anderson, “Ancient Rhetorical Theory and Paul," Theological Studies 59, no. 4 (1998): 760.

${ }^{8}$ Jewett, Epp, and Kotansky, Romans: A Commentary, 669.

${ }^{9}$ Philip F. Esler, "Ancient Oleiculture and Ethnic Differentiation: The Meaning of the Olive-Tree Image in Romans 11," Journal for the Study of the New Testament 26, no. 1 (July 22, 2003): 109-10, https://doi.org/10.1177/0142064X0302600106.

${ }^{10}$ Esler, 107-8.

${ }^{11}$ Jewett, Epp, and Kotansky, Romans: A Commentary, 681.

${ }^{12}$ Douglas J. Moo, The Epistle to the Romans, New International Commentary on the New Testament (Grand Rapids, MI, USA: Eerdmans, 1996), 700-701.

${ }^{13}$ A G Baxter and John A Ziesler, "Paul and Arboriculture: Romans 11.17-24," Journal for the Study of the New Testament 7, no. 24 (1985): 25-32.

${ }^{14}$ Moo, The Epistle to the Romans, 703.

15 Joshua Garroway, Paul's Gentile-Jews: Neither Jew nor Gentile, but Both (New York: Palgrave Macmillan, 2012), 141.

${ }^{16}$ Henry L Ellison, The Mystery of Israel: An Expsition of Romans 9-11 (Paternoster Press, 1976), 8687.

${ }^{17}$ James D G Dunn, Romans 9-16 (Word Books, 1988), 659.

${ }^{18}$ Thomas R Schreiner, Romans, vol. 6 (Baker Academic, 1998), 600-601.

${ }^{19}$ Jewett, Epp, and Kotansky, Romans: A Commentary, 683; Moo, The Epistle to the Romans, 699.

${ }^{20}$ Moo, 699.

${ }^{21}$ William D Davies, Jewish and Pauline Studies (SPCK, 1984), 159-60.

${ }^{22}$ Jewett, Epp, and Kotansky, Romans: A Commentary, 683-84.

${ }^{23}$ Moo, The Epistle to the Romans, 701. Moo menggunakan kata "if' yang diterjemahkan menjadi "jika" sebagai prasyarat untuk klausa selanjutnya "then", sedangkan LAI menerjemahkan menjadi "karena itu". Terjemahan LAI sedikit menghilangkan pengandaian pada ayat setelahnya.

24 Arland J Hultgren, Paul's Letter to the Romans: A Commentary (Wm. B. Eerdmans Publishing, 2011), 409.

${ }^{25}$ (Rm 12:13; 15:26, 27; 1 Kor 1:9; 9:23; 10:16; 2 Kor 1:7; 6:14; 8:4, 23; 9:13; 13:13; Flp 1:5, 7; 2:1; 3:10; 4:14-15; Flm 6, 17; Gal 2:9; 6:6).

${ }^{26}$ Jewett, Epp, and Kotansky, Romans: A Commentary, 685.

${ }^{27}$ Moo, The Epistle to the Romans, 703.

${ }^{28}$ Dunn, Romans 9-16, 673.

${ }^{29}$ Ernst Kasemann, Commentary on Romans (Wm. B. Eerdmans Publishing, 1994), 310,

${ }^{30}$ Caroline Johnson Hodge, "“A Light to the Nations': The Role of Israel in Romans 9-11," in Reading Paul's Letter to the Romans, ed. Jerry L. Sumney, vol. 73 (Atlanta: Society of Biblical Literature, 2012), 182.

${ }^{31}$ Yonky Karman, Bunga Rampai Teologi Perjanjian Lama (Jakarta: BPK Gunung Mulia, 2015), 118.

${ }^{32}$ Schreiner, Romans, 6:608.

${ }^{33}$ Karman, 118. 


\section{DAFTAR PUSTAKA}

Anderson, R. "Ancient Rhetorical Theory and Paul.” Theological Studies 59, no. 4 (1998): 760.

Banks, Marcus, and David Zeitlyn. Visual Methods in Social Research. Sage, 2015.

Barrett, Charles K. The Epistle to the Romans, Revised. Black's New Testament Commentary. Peabody, Mass: Hendrickson Publishers, 1991.

Baxter, A G, and John A Ziesler. "Paul and Arboriculture: Romans 11.17-24." Journal for the Study of the New Testament 7, no. 24 (1985): 25-32.

Davies, William D. Jewish and Pauline Studies. SPCK, 1984.

Dunn, James D G. Romans 9-16. Word Books, 1988.

Ellison, Henry L. The Mystery of Israel: An Expsition of Romans 9-11. Paternoster Press, 1976.

Ernst Kasemann. Commentary on Romans. Wm. B. Eerdmans Publishing, 1994. https://books.google.co.id/books/about/Commentary_on_Romans.html?id=537 vyNBFfokC\&redir_esc=y.

Esler, Philip F. "Ancient Oleiculture and Ethnic Differentiation: The Meaning of the Olive-Tree Image in Romans 11." Journal for the Study of the New Testament 26, no. 1 (July $22, \quad 2003):$ 103-24. https://doi.org/10.1177/0142064X0302600106.

Garroway, Joshua. Paul's Gentile-Jews: Neither Jew nor Gentile, but Both. New York: Palgrave Macmillan, 2012.

Getty, Mary Ann. "Paul and the Salvation of Israel: A Perspective on Romans 9-11." The Catholic Biblical Quarterly 50, no. 3 (1988): 456-69.

Gordon, Benjamin D. "On the Sanctity of Mixtures and Branches: Two Halakic Sayings in Romans 11:16-24." Journal of Biblical Literature. Society of Biblical Literature, 2016. https://doi.org/10.15699/jbl.1352.2016.2783.

Hodge, Caroline Johnson. “"A Light to the Nations': The Role of Israel in Romans 911." In Reading Paul's Letter to the Romans, edited by Jerry L. Sumney, Vol. 73. Atlanta: Society of Biblical Literature, 2012.

Hultgren, Arland J. Paul's Letter to the Romans: A Commentary. Wm. B. Eerdmans Publishing, 2011. 
Jewett, Robert, Eldon Jay Epp, and Roy David Kotansky. Romans: A Commentary. Hermeneia. Minneapolis, MN: Fortress Press, 2006.

Karman, Yonky. Bunga Rampai Teologi Perjanjian Lama. Jakarta: BPK Gunung Mulia, 2015.

Moo, Douglas J. The Epistle to the Romans. New International Commentary on the New Testament. Grand Rapids, MI, USA: Eerdmans, 1996.

Schreiner, Thomas R. Romans. Vol. 6. Baker Academic, 1998. 